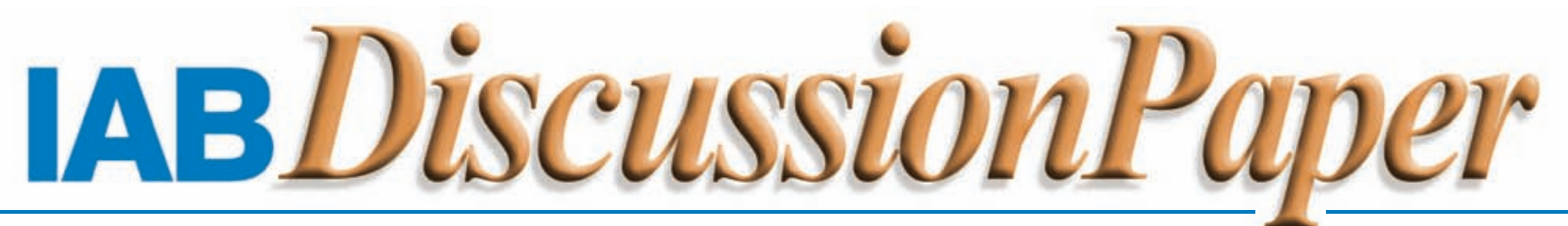

Beiträge zum wissenschaftlichen Dialog aus dem Institut für Arbeitsmarkt- und Berufsforschung

No. 19/2005

\title{
The Interaction of Labor Market Regulation and Labor Market Policies in Welfare State Reform
}

Werner Eichhorst and Regina Konle-Seidl 


\title{
The Interaction of Labor Market Regulation and Labor Market Policies in Welfare State Reform
}

\author{
Werner Eichhorst (IZA Bonn) and Regina Konle-Seidl (IAB)
}

Auch mit seiner neuen Reihe „IAB-Discussion Paper“ will das Forschungsinstitut der Bundesagentur für Arbeit den Dialog mit der externen Wissenschaft intensivieren. Durch die rasche Verbreitung von Forschungsergebnissen über das Internet soll noch vor Drucklegung Kritik angeregt und Qualität gesichert werden.

\footnotetext{
Also with its new series "IAB Discussion Paper" the research institute of the German Federal Employment Agency wants to intensify dialogue with external science. By the rapid spreading of research results via Internet still before printing criticism shall be stimulated and quality shall be ensured.
} 


\section{Inhaltsverzeichnis}

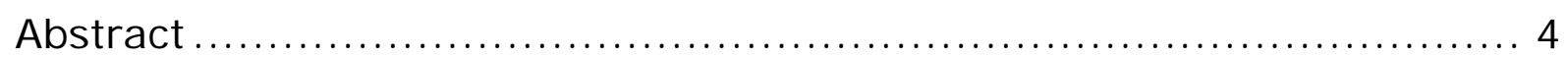

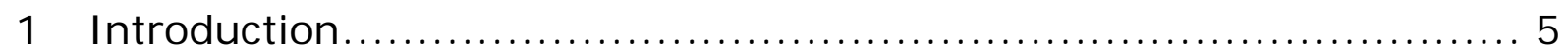

2 Labor Market Regulation and Labor Market Policies.................... 6

2.1 Different Mechanisms of Income and Employment Security ............ 6

2.2 Effects on Employment Performance ................................. 7

3 The Role of Policy Complementarities in Labor Market Reform ......... 10

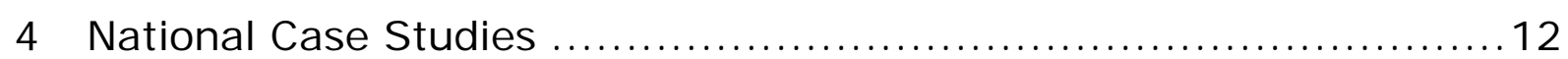

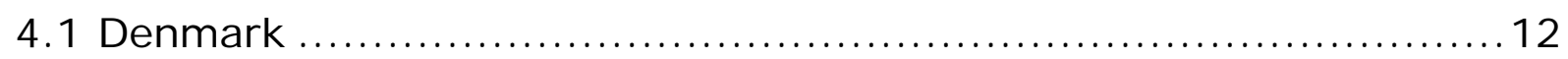

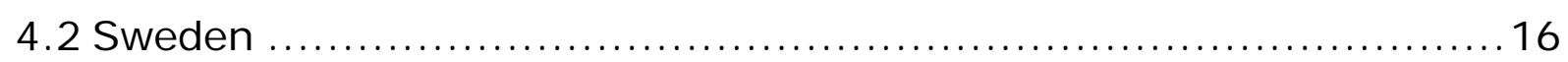

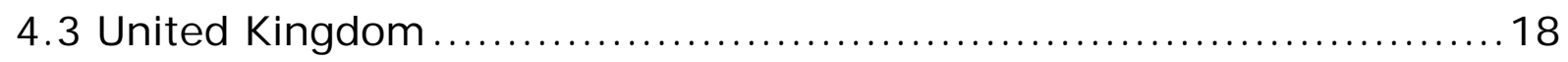

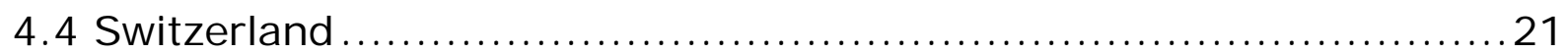

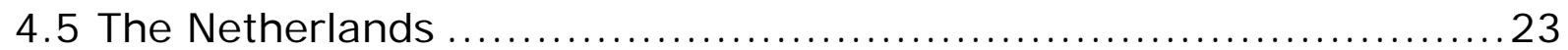

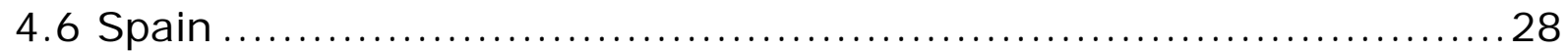

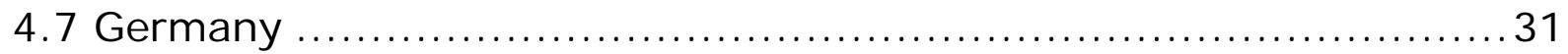

5 Comparative Analysis: Different Paths of Reform..................... 33

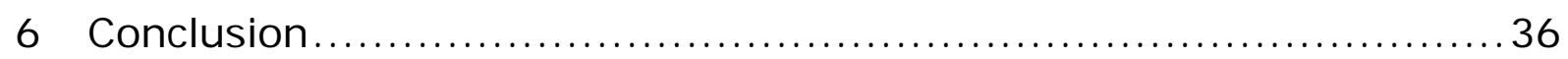

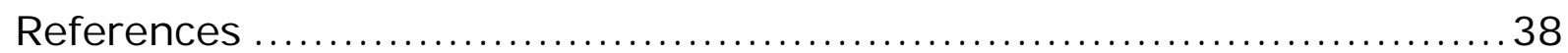

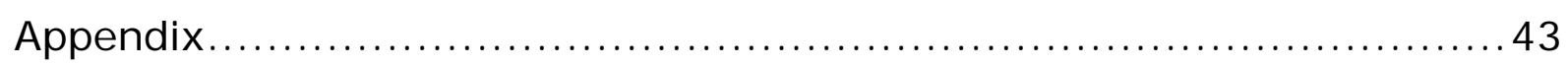




\section{Abstract}

Employment protection legislation, unemployment benefits and active labor market policy are Janus-faced institutions. On the one hand they are devices of insurance against labor market risk that provide income and employment security. On the other hand they influence the capacities of labor markets to adapt to changing economic conditions since institutional features of the welfare state also affect actors' economic adaptation strategies. Insufficient labor market adaptability results in higher and more persistent unemployment. Hence, in order to increase the adaptability of European labor markets, reforms had to address these closely interacting policy areas. The first aim of the paper is to describe recent reforms of employment protection, unemployment insurance and active labor market policies in different European welfare states (Denmark, Sweden, the United Kingdom, Switzerland, the Netherlands, Spain and Germany). The paper shows whether and to what extent national policy patterns converge in the direction of a new balance of flexibility and security with employment protection being eased and labor market policies being "activated" through a combination of "carrots and sticks". Secondly, in terms of the political economy of welfare state reforms, the paper will answer the question whether consistent reforms of the three institutions are more likely in political systems characterized by relative strong government and/or social partnership since such institutional prerequisites may favor "package deals" across policy areas. 


\section{Introduction}

In order to explain differences in labor market performance, factors determining the capacity of economic actors to adapt to structural shifts or business cycle variations have to be taken into account. In this context, employment protection legislation, unemployment benefits and active labor market policy are Janus-faced institutions. On the one hand they partly determine the overall adaptability of labor markets in that they influence actors' behavior. On the other hand, they also constitute welfare state provisions of insurance against labor market risk. They not only determine the level of income and employment security but also the chances of individual reemployment after unemployment. Since there are complementarities between these institutions, reforms to increase the dynamics of European labor markets had to address more than one area. This paper will first describe recent reform sequences affecting employment protection, unemployment benefits and active labor market policies in a number of European countries that belong to different regimes of welfare states: Denmark, Sweden, the United Kingdom, Switzerland, the Netherlands, Spain and Germany. The paper shows whether and to what extent national policy patterns actually converge in the direction of a higher level of adaptability with employment protection being eased and labor market policies being activated through a combination of "carrots and sticks". Second, regarding the politics of reforms, the paper tries to answer the question whether consistent reforms of the three insurance devices are more likely in political systems characterized by strong government and/or social partnership since such institutional prerequisites may favor reform packages. 


\section{Labor Market Regulation and Labor Market Po- licies}

\subsection{Different Mechanisms of I ncome and Employment Security}

Differentials in national labor market performance can to a significant extent be explained by the capacity of economic actors to adapt to structural shifts or business cycle variations. This capacity is determined by institutional factors. The higher the labor market adaptability, the less severe will be the problem of persistent unemployment. As regards the set of relevant labor market institutions, theoretical and empirical research in economics (Layard/Nickell/Jackman 1991, Blanchard/Wolfers 2000) but also comparative welfare state research (Scharpf 2000, Hemerijck/Schludi 2000, Auer 2000) suggest that different regimes of income and employment security are crucial factors determining the level of unemployment as well as the probability of reemployment after individual unemployment spells. Employment protection legislation (EPL), i.e. restrictions on individual dismissals, temporary contracts and temporary work agencies, passive labor market policies, i.e. the level and duration of unemployment benefits, and the system of active labor market policies (ALMP) have two meanings in this context: first, they are important features of national welfare states which provide insurance against labor market risks; second, they influence structures and dynamics of labor markets. Besides EPL, ALMP and the benefit system, taxation and wage bargaining structures also influence relevant institutions. But as we focus on mechanisms of insurance against labor market risk, taxation and wage setting will not be the focus of our analysis but constitute an integral part of the institutional framework of analysis.

Legal provisions on employment protection and unemployment insurance change the operation of labor markets fundamentally and interfere with a 'pure' market in that they provide a certain level of security that would be absent otherwise: employment protection legislation enhances the stability of existing jobs and thus leads to higher employment security; through severance payments it can provide some income security to dismissed workers. Income security means stabilization of individual income in case of unemployment by means of "passive" labor market policies, i.e. unem- 
ployment compensation and early retirement for labor market reasons. Reemployment security means a higher probability of returning to gainful employment through job placement, participation in active labor market policy schemes, but also "activating" interventions during the unemployment spell.

Combinations of employment protection legislation, active and passive labor market policies differ over time and space (OECD 2004, Boeri/CondeRuiz/Galasso 2003). A variety of arrangements can be observed in specific clusters of welfare states (Esping-Andersen 1990, Esping-Andersen/Regini 2000, Arts/Gelissen 2002, Ferrera 1996, Wilthagen/van Velzen 2004): with reasonable simplification we can argue that 'liberal' welfare states like the UK not only provide low EPL but also lower levels of out-of-work benefits and less active labor market policies, while Switzerland is 'hybrid' since it provides low EPL but more generous benefits and active labor market policies. The same holds for Denmark which is usually joined by Sweden in the 'Scandinavian' cluster since both are big spenders on active and passive labor market policies, although there is no clear pattern in EPL. In 'conservative' welfare states in continental Europe, e.g. in Germany and the Netherlands, EPL is rather strict while considerable resources are spent on active and passive labor market policies. Finally 'southern' welfare states such as Spain can roughly be described by strict EPL and lower levels of benefits and a less intense active labor market policy.

\subsection{Effects on Employment Performance}

As regards the effects of the diverse security mechanisms, we can identify positive and negative effects of interference with markets: Strict EPL can stabilize employment and income, strengthen commitment of workers to their firm and induce more investment of employers and employees in firm-specific human capital, but restrictive regulation reduces labor market adaptability by inhibiting labor market transitions, i.e. job-to-job mobility. Once people are made redundant this can result in longer unemployment spells and lead to higher long-term unemployment. In particular it can hamper employment of the non-core labor, i.e. older workers, youth and females, and lead to a severe segmentation of labor markets since employment protection stabilizes the jobs of labor market insiders, mainly 
prime-aged men, at the expense of outsiders and entrants (Lindbeck/Snower 1988). Easing restrictions on fixed-term contracts and temporary agency work increases flexibility at the margin and might, therefore, contribute to stronger employment growth in flexible jobs which provide entry opportunities for labor market entrants. But as long as dismissal protection for regular jobs remains unchanged, the creation of flexible jobs may coincide with severe labor market segmentation since transitions from flexible to stable jobs remain difficult (Saint-Paul 2002). From a macroeconomic point of view stricter EPL raises the costs of labor turnover. As with taxes on labor, if insiders can use their power to force firms to bear the costs generated by EPL, unemployment will increase. If firms are compensated for by wage adjustments, unemployment will remain stable. Even in this case the relative costs of hiring and firing rise and, as a consequence, the flows into and out of unemployment will be smaller which means fewer but longer unemployment spells (OECD 1999, 2004).

As regards unemployment benefits one can argue that a generous 'passive' benefit system will exert upward pressure on wages at given levels of unemployment, both because it reduces the fear of job loss on part of employees and because the unemployed can afford to be more "picky" when looking for a new job. Hence, unemployment benefits can increase the duration of individual unemployment spells since the pressure to search for a new job is lower, the longer and the more generous awarded unemployment benefits are. By raising the reservation wage unemployment insurance makes job seekers more "ambitious" regarding the earnings level to be achieved. Thus, it reduces the need for wage concessions which in turn leads to lower wage flexibility. On the other hand, unemployment benefits work as a search subsidy so that jobseekers can wait and choose a job offer that matches their profile better than an offer accepted because of financial need. Hence, unemployment insurance can contribute to more stable and productive matches on the labor market (Gangl 2002).

The impact of a relatively generous benefit system might be offset by suitable active policy measures that raise effective labor supply by making the unemployed more willing to accept jobs or by making them more attractive to prospective employers (Martin/Grubb 2001). Combining a gen- 
erous benefit system with well-designed active labor market programs, strictly applied search criteria, tests for benefit eligibility and labor market availability will lower unemployment (Nickell/van Ours 2000). While effective labor market policies might make the labor market more adaptable by providing support for up-to-date qualification or compensation of hiring disadvantages, participation in active labor market programs can also lead to lock-in effects that reduce job search efforts. That may be ineffective with respect to the improvement of individual chances of being hired after termination of the measure and may go along with high dead-weight and substitution effects on the macro-economic level. It may even have adverse effects on non-participants through crowding-out effects. Nonparticipants could also be harmed by negative side-effects of taxes or social security contributions that are raised in order to cover expenditure for labor market schemes.

If employment protection and labor market policies interact differently, we would suppose the dynamics of labor markets to differ: restrictive employment protection will be associated with a larger share of the long-term unemployed and a lower participation rate of women, the young and older workers. The same might be expected from generous unemployment benefits as long as active or activating labor market policies do not intervene in the unemployment spell. But different models and levels of security can be sustained as long as overall labor market adaptability is sufficient. Strict employment protection plus generous benefits and rather passive labor market policies might be the worst. Higher levels of unemployment benefits can be compatible with good labor market performance if benefit receipt is made conditional upon individual job search and acceptance of public job offers or training measures. Therefore, in order to reduce unemployment persistence, reforms have to aim at increasing overall labor market adaptability. That means easing employment protection, making active labor market policies more effective in terms of their contribution to qualification and reintegration into the labor market and strengthening work incentives of benefit recipients by activation strategies (Cox 1998, Kvist 2002, Clasen/Kvist/van Oorschot 2001). The concrete design of reforms, however, can differ according to the properties of the system in place. 


\section{The Role of Policy Complementarities in Labor Market Reform}

Since high labor market adaptability depends on an effective institutional arrangement of several related policy areas, reforms have to tackle more than only one policy field to create an institutional setting conducive to high employment growth and low unemployment. There are positive complementarities between reforms in a double meaning (Coe/Snower 1997, Orszag/Snower 1999): on the one hand, positive economic complementarities can make reforms more effective because coordinated changes in related policy areas cause mutually reinforcing effects on labor market dynamics. Absence of complementary reforms in adjacent policy areas is a major reason for disappointing effects of isolated reforms. E.g. we can expect active or activating labor market policies to be more effective if flexible labor market regulation allows for the dynamic creation of new jobs. In turn, activating the long-term unemployed will be less important if unemployment benefits are low and, therefore, create strong incentives to take up low-paid jobs. On the other hand, political complementarities can facilitate reforms since coordinated changes across policy areas may be more practicable in political terms as package deals can take opposition from actors fearing short-term losses into account. Hence, policy-makers could overcome insider resistance more easily (Lindbeck/Snower 1988, SaintPaul 2004). E.g., lower dismissal protection may be less worrying to insiders if unemployment benefits and reemployment opportunities reassure them (OECD 2004).

Effective use can be made of policy complementarities in two different ways: first, reforms can be part of package deals that establish a plausible set of reforms; second, reforms in one policy area can be complemented by subsequent reforms in another policy area so that the sequential order can generate more powerful economic effects and/or stronger public support. Hence, we expect the paths of reform to differ not only due to diverging points of departure in the sense of 'path dependence' (Pierson 2000). We also presume that process and outcome of labor market reforms depend on the capacity of national political systems to implement complementary reforms. Therefore, it is plausible to argue that the capacity to manage policy complementarities is more pronounced if one or both of the following conditions are met: 
1. Government is strong in the sense that it possesses the capacity to formulate and implement reform strategies that affect different policy areas. Government capacities are weaker if veto points such as second chambers in federal systems, the necessity of social partner negotiations, constitutional autonomy in wage setting or self-administration in social security exist (I mmergut 1992, Jochem 2003).

2. However, in countries where control of some areas of economic policy is shared with the social partners, policy complementarities can only be mobilized if government can coordinate reforms with employers' associations and trade unions. Effective tripartite coordination depends both on the structure of interest associations and on state capacities. Agreement on 'social pacts' is facilitated by centralized and uncontested peak associations, institutionalized consultations on economic issues as well as by government's capacity to formulate an agenda for tripartite negotiations and credibly threat social partners with unilateral intervention (Ebbinghaus/Hassel 2000, Hassel 2003).

These factors facilitate the management of policy complementarities. But attempts at labor market reforms have to be triggered by actors' assessment that existing institutions have to be modified in order to increase labor market performance (Hemerijck/Schludi 2000). This, in turn, relies on the perception of labor market problems and feasible options. It may be furthered by policy consulting that provides actors with analytical and conceptual input and hints at policy interactions that might be neglected otherwise. But policy preferences of the wider public also play a role. Reforms are easier to implement if there is a general consensus on societal problems and objectives which can be generated by political leadership that is able to frame the need for reform and to shape the reform path (Cox 2001). If no broad consensus exists, reforms depend upon support of pivotal groups. Hence, we can expect that reforms to increase labor market adaptability are more probable if groups that might benefit from them have ample size (Dolado/García-Serrano/J imeno-Serrano 2002, Saint-Paul 2002). 


\section{National Case Studies}

Our sample of seven European countries was selected for two reasons: First, we were interested in covering different welfare state and labor market regimes. Second, we wanted to focus our analysis on a number of countries where significant reforms were implemented over the last decade. The following section provides a historical account of labor market reforms supplementing the summary indicators on institutional features and changes that are readily available from the OECD except for the intensity of activation.

--- table 1 about here ---

We analyze the design of reforms in employment protection legislation, active and passive labor market policies since the early nineties in order to identify underlying strategies and the major factors influencing the choice of reform paths. Two questions guide our research: (1) what did the different countries do (2) and why did they do it that way? As regards policy outcomes in terms of labor market adaptability we broadly refer to selected general labor market indicators such as the standardized unemployment rate and the employment/population ratio without claiming that the reforms analyzed in our paper had direct and clear-cut effects on these outcome variables. In addition, we consider the share of the longterm unemployed as a supplementary variable for labor market segmentation and unemployment persistence since data on labor market mobility, i.e. transitions and tenure, are not available for all countries and years.

-.- table 2 about here -.-

\subsection{Denmark}

The Danish welfare model has a 'hybrid' character. Denmark is close to the liberal cluster when it comes to employment protection but, when measured by net replacement rates of unemployment benefits and by expenditure on active labor market policy, Denmark is part of the Scandinavian model. However, the system of labor market policies in place in the early nineties could not prevent a considerable increase in open unemployment. To counter this, a sequence of reforms was implemented that 
started in 1994 (Andersen 2002a, 2002b, Madsen 2004, Björklund 2000, van Oorschot/Abrahamson 2003, Dingeldey 2004).

Through a series of reform steps Denmark shifted away from a rather "passive" type of labor market policies resulting in long periods of benefits dependency and withdrawal from the labor force. Based on reports by the independent experts of the Social Commission and the tripartite Zeuthen Committee published in 1992/93 which referred to constitutional principles of Danish social policy and emphasized the need to combine "rights and obligations" of the unemployed, a more activating approach was adopted by the new Social Democratic government in 1994, which could mobilize widespread societal support (Cox 2001). On the one hand, this meant that more attention was to be paid to individual jobseekers' needs and to support job search efforts but also to monitor these activities. Through binding job seekers' agreements benefit receipt was made conditional upon sufficient job search efforts and acceptance of job offers or labor market programs. Availability criteria become more demanding in terms of justification for refusal of jobs. Failure to meet these requirements meant withdrawal of benefits. Hence, receipt of unemployment benefits became less permissive while the benefit level itself was not cut. It still is one of the highest in Europe, in particular with respect to replacement rates for lowwage earners. This holds for both contribution-based voluntary unemployment insurance and means-tested unemployment assistance for the unemployed not entitled to insurance benefits (OECD 2004).

The maximum duration of unemployment benefits was reduced from $91 / 2$ years to seven and later to four years. Since 1995 mandatory activation in the sense of participation in active labor market programs lasting up to three years set in after four years of unemployment. At the same time participation in active schemes did not lead to renewal of benefit entitlements anymore. On the other hand participation in those active labor market programs that were expected to improve individual prospects such as training courses and hiring subsidies expanded significantly. The high participation of employed persons in job-related further training is particularly remarkable. In order to lower registered unemployment several schemes that reduced labor supply were implemented. A considerable number of older workers withdrew from the labor market via early retirement. Employed, but also unemployed persons could enter paid leave 
schemes for further training, child rearing or personal reasons ("sabbatical").

In combination with a further increase in public sector employment these reforms led to a striking decline in registered unemployment and longterm unemployment. However, to counter labor shortages and fiscal pressure on the welfare state that arose in the second half of the nineties, Danish policies aimed at mobilizing additional labor and activating the unemployed more effectively. Hence, early retirement and leave schemes were curtailed and partially abolished after 1996. Since 1999 mandatory activation - particularly addressing youth, older workers and the long-term unemployed - set in after only one year of unemployment, and unemployment insurance benefits are paid for only four years. In the late nineties availability criteria became even more restrictive. Selection of training measures was oriented towards labor market needs instead of individual preferences. The social partners were involved in reorganizing the public employment service with more responsibilities being devolved to the regional and local level.

The third phase of labor market policy reform set in after a shift in power in 2002. A conservative-liberal coalition emphasized activation of people outside of the labor market by means of integrating the schemes for insured and non-insured jobseekers and streamlining policy instruments. This was complemented by even stricter job search requirements laid down in individual action plans with the activation period starting from the first day of unemployment now. For the first time in Danish welfare state history in-work benefits were introduced to strengthen work incentives when taking up a low-paid job through combining partial benefit receipt and earned income. This policy meant a shift away from public employment and qualification which had been advocated by the Social Democrats in the past.

In Denmark, active and passive labor market policies go hand in hand with liberal employment protection. There is no dismissal protection as in the continental European countries or Sweden. Employers are free to terminate employment relationships but have to pay for the first two days of unemployment. Severance pay is mandatory only after long tenure. There are no restrictions on fixed-term contracts, and certain provisions regulating temporary work agencies were eased in the early nineties. 
ing temporary work agencies were eased in the early nineties. Further changes were not on the political agenda. Hence, the Danish economy, which is dominated by small and medium-sized firms, benefits from a high level of labor market flexibility (OECD 2004, Madsen 2002a, 2002b). Low employment protection is acceptable to strong trade unions since it is compensated for by relatively generous income replacement for the unemployed with low prior earnings who experience a higher risk of unemployment, while active and activating labor market policies support reemployment. Hence, employment tenure is rather short and unemployment experience is more frequent in Denmark, but individual unemployment spells are short and the share of the long-term unemployed low. However, until the most recent attempts at activating inactive persons, part of the reduction in open unemployment was due to the reduction in labor supply via early retirement and leave schemes.

The long sequence of reforms in active and activating labor market policy was enabled by strong involvement of the peak associations of the social partners in policy-making, policy advice through commissions and committees, continuous discussion of economic issues as well as by broad public support of the reform objectives. Government, on the other hand, could threaten to intervene in wage policies. Uncommonly for Denmark, the Social Democrats had a reliable majority in parliament after 1994 . In this situation the social partners supported economic recovery by wage moderation. The Danish concertation structures allowed for the pragmatic fine-tuning of a more and more coherent activation strategy within a generally accepted policy framework. This implied the revocation of some dead-end policies such as the measures that reduced labor supply and kept benefit dependency at a high level in the mid-nineties. But we have to bear in mind that the Danish flexibility-security nexus is the outcome of a long historical process involving a series of negotiations and compromises between the social partners about the development of the welfare state and the gradual implementation of a more activating profile of labor market policy (Benner/Vad 2000, Madsen 2005). 


\subsection{Sweden}

Sweden is often classified as most similar to Denmark in its strong emphasis on active labor market policy. However, we can identify notable differences and diverging reform trajectories. In contrast to the liberal system in Denmark, employment protection legislation in Sweden is more similar to continental European countries. Dismissal protection for regular jobs is as restrictive as in the Netherlands or Germany. As in those countries there have not been significant reforms over the period observed. In 1994 the conservative government tried to ease dismissal protection aiming to soften the principle of "first in, first out", i.e. protection proportional to job tenure, in favor of core staff, and at lengthening the probationary period. These reforms were withdrawn by the Social Democrats in 1995 but selection of staff to be dismissed does not follow social criteria in smaller enterprises with less than ten employees anymore. In addition, Swedish employers can hire workers on fixed-term contracts which are much less regulated than regular jobs. To increase labor market flexibility, regulation of temporary work agencies was liberalized over the eighties until the late nineties.

Active labor market policy was part of the classical Rehn-Meidner model governing the Swedish economic policy over decades. In combination with a solidaristic and egalitarian wage policy, active labor market policy should work to increase the occupational and regional mobility of workers made redundant in declining industries to expanding sectors where labor shortages arise. Hence, training and mobility support featured prominently in Swedish active labor market policy (Calmfors/Forslund/Hemström 2001, Björklund 2000).

The picture changed completely in the nineties. Confronted with a severe economic crisis and a steep increase in open unemployment that made it hard to place the unemployed in dynamic regions or sectors, the focus of active labor market policy was redirected towards locally oriented training programs and public relief jobs. Participation was expanded in order to reduce registered unemployment. The system was changed again in the late nineties. Based on a comprehensive evaluation of labor market policies that found little positive effects on reemployment (Calmfors/Forslund/Hemström 2001), the volume of resources spent on these 
schemes was cut significantly so that the number of participants shrank considerably.

With respect to unemployment insurance this meant that since 2000 participation in active schemes did not renew entitlements to unemployment benefits anymore. At the same time an "activation guarantee" was introduced (OECD 2003). After 60 weeks of unemployment benefit receipt, a period without much intervention by the public employment service, unemployed people are assessed to find out if they have a realistic chance to find new jobs on their own or if they need assistance. In the first case benefit receipt continues for an additional period of 60 weeks, in the second case, or if they are still unemployed after 120 weeks, the long-term unemployed have to participate in coaching seminars that aim at encouraging job search activities. If that does not work, supplementary support is provided through training courses. As in Denmark this is part of a bilateral agreement between job seekers and the PES. Activation guarantee schemes are full-time, but do not have a clear maximum duration. They are implemented locally under the joint supervision of the PES and the municipalities. Following the general trend availability criteria became stricter in 2001. To some extent active labor market programs are used as work tests to assess actual availability of jobseekers. However, the empirical evidence shows that activation is less consistent than in Denmark, the UK or the Netherlands and long-term unemployment grew, albeit on a low level. Despite some changes in the early and mid-nineties, unemployment benefits are still quite generous in Sweden: the formal replacement rate was $90 \%$, but was reduced to $80 \%$ in 1994 and to $75 \%$ in 1996 , but rose again to $80 \%$ in 1997 . While there are five waiting days now, maximum duration of earnings-related benefits was extended from 300 to 600 days with the implementation of the "activation guarantee".

So after a phase of classical active labor market policies and a "passive" approach to cushion the recession of the early nineties, Sweden embarked on the activation path while reducing resources and participants inflow. Even today qualification of jobseekers through training on the job or through external courses is a prominent feature of Swedish active labor market policy. It has clear priority over placing the unemployed in lowwage jobs. Activation, on the other hand, was introduced later and with a more cautious approach than in other countries. Hence, the Swedish sys- 
tem still is not as strict but more permissive than the Danish or the British one in the sense that "carrots" are more important than "sticks".

In contrast to the well-established record of Swedish corporatist concertation, the most recent reforms and also the changes in labor market policy were implemented through government action (Jochem 2003a, 2003b). However, after a breakdown in the early nineties, sectoral and subsequent national-level concertation of wage policy could support the recovery of the Swedish economy.

\subsection{United Kingdom}

The 'liberal' British welfare state is characterized by a relatively low level of employment protection and unemployment benefits. In the UK unemployment benefits are part of the mandatory social security system for all employees. The system makes a distinction between contribution-based and income-based benefits with the former requiring a minimum amount of contributions whereas income-based benefits are means-tested and depend on the family situation. The maximum duration of contribution based benefits is 182 days while income-based benefits have unlimited duration. The flat-rate benefit is only $85 €$ a week for unemployed people older than 25 years so that the unemployed have to make significant wage concessions when taking up new jobs.

In the UK active labor market policies always played a much less prominent role than in Scandinavian welfare states both in terms of expenditure and participant inflow. Early reforms in the eighties implemented by the Conservative government first addressed benefits for the unemployed. Although the benefit level already was one of the lowest in Europe, it was reduced further by another $25 \%$. Conditions for benefit receipt were tightened for young people. In 1987 the new "restart program" provided closer monitoring of job search activities and more intense counseling and job placement for the long-term unemployed. This reduced individual unemployment duration (Dolton/O'Neill 1997). The "Jobseekers' Allowance" replaced this scheme in 1996 and increased job search requirements even further by shorter contact intervals with the public employment service and the duty to provide evidence of individual job search activities. Recipients of unemployment benefits have to accept low-paid job offers. 
The Conservative government based its policies on the assumption that benefit receipt is viable only if certain job search obligations are met. To avoid long-term benefit dependency access to benefits had to be balanced by the duty to accept available job offers. Otherwise benefit receipt would be questioned. To strengthen work incentives the "Family Credit", introduced in 1988, provided in-work benefits for low-wage earners and families with low income. Depending on the number of children in the household and the number of hours worked a means-tested supplementary benefit was paid to top up low wages.

Whereas the Conservatives put major stress on the "sticks", New Labor that came into power in 1997 shifted the emphasis a bit towards the "carrots" without reducing the strictness of the British way of activation and the emphasis on rights and duties of the unemployed. Activation policies were complemented by a notable expansion in active labor market schemes. Hence, the role of the state became a more active one in accordance with New Labor's conception of a "Third Way" between market liberalism and traditional social policies and an implicit contract between the state and its citizens. However, participation in active schemes that aim at increasing individual employability was not only conceived as a supportive measure but was also used as an effective work test to assess labor market availability.

The most important features of New Labor's welfare-to-work strategy are the targeted "New Deal" schemes addressing different groups of unemployed persons and benefit recipients that are not unemployed in formal terms but receive disability and equivalent benefits such as young people, older workers, the disabled or single parents. To make work pay and reduce poverty traps inherent in a system based on means-tested transfers, the British in-work benefit schemes were expanded significantly. In 1999 more generous tax benefits for low-wage earners with dependent children ("Working Families' Tax Credit") were introduced. In 2003, the new "Working Tax Credit" addressed single low-wage earners for the first time. The New Deals fit into a long-term strategy to make non-employment less attractive for working-age persons and to not only increase work incentives but also employability through activating labor market policies. 
In contrast to Sweden, but similar to Denmark, the United Kingdom had a liberal regime of employment protection at the beginning of the nineties which has not been changed significantly and is associated with short employment tenure. This holds not only for fixed-term contracts and temporary agency work but also for individual dismissal protection. Some marginal reforms under New Labor lead to a slight increase in regulation intensity such as halving the trial period in 2000 and restricting maximum duration of fixed-term employment from unlimited to four years in 2002 . Action of the Conservative government in the eighties and early nineties mainly addressed reforms restricting trade union power and decentralizing wage setting. In 1993 minimum wages set by Wage Councils were abolished and reintroduced on a statutory basis in 1999 by New Labor. Although this restricted wage flexibility to a certain extent, it did not do much harm, given the actual level of the minimum wage. In a system with wide wage dispersion, the introduction of the statutory minimum wage can be interpreted as part of the "make work pay" approach since it provided an effective wage floor thus making paid work more attractive for low-wage earners.

Reforms of labor institutions in the UK are results of a long sequence that started in reaction to severe economic problems in the early eighties under the conservative government and addressed wage setting first. Active or activating labor market policies were not an issue until the shift in power in 1998, with New Labor implementing the New Deal schemes that introduced noteworthy active labor market programs for the first time after a period characterized by the virtual absence of labor market policy in the UK. However, active labor market policies followed the paradigm of strict activation with intensive monitoring of job search activities and providing effective work tests. To strengthen work incentives for the lowskilled unemployed and to reduce poverty in work stemming from high wage inequality, this was complemented by in-work benefits. These changes contributed to a notable decline in both unemployment and longterm unemployment. But we have to bear in mind that part of open unemployment is hidden by the disability scheme. The capability to adopt and implement these reforms was high due to the institutional strength of British governments resulting from majority voting, the absence of federalism and the relatively weak role of the trade unions after initial reforms 
restricting their influence (Dorey 2002). So the subsequent governments could implement reform sequences in accordance with they programmatic stance: the Conservatives with a liberal, market-oriented approach, New Labor with its vision of an "enabling state". The combination of both seems to fit with the overall setting of the British labor market.

\subsection{Switzerland}

Although the Swiss welfare state has a different origin and a much shorter history than the Danish one, it is now quite similar and could also be best described as 'hybrid' between liberal and Scandinavian welfare regime. Both labor market regimes combine low employment protection with generous unemployment benefits and strict activation.

On the one hand, the flexibility of the Swiss labor market results from a low level of labor market regulation in terms of employment protection and from decentralized industrial relations. Dismissal protection is weak since notice periods are short and employers do not have to justify termination of contracts. So there is not much room for severance pay except for employees with long tenure or for legal action. In contrast to Denmark, however, collective agreements are much less relevant for the definition of wages and working conditions in Switzerland. Due to firm-based negotiations wage flexibility is high although wage dispersion remains limited. Together with a low level of non-wage labor costs the adaptability of the Swiss labor market is high which is shown by considerable mobility on the labor market and an impressive labor market performance in terms of high employment rates and low unemployment despite the fact that the Swiss economy suffered from low growth rates over the nineties (Straubhaar/Werner 2003).

Whereas these institutional features did not change over the period under scrutiny, active labor market policies and unemployment insurance underwent fundamental modifications since the early nineties. Until the late seventies there was only rudimentary unemployment insurance, and until the early nineties active labor market policies were negligible. Unemployment benefits became more generous over the eighties with a maximum duration of two years and a benefit level of 70 to $80 \%$ of previous earnings depending on household composition. Faced with a sharp increase in 
open unemployment and a growing share of the long-term unemployed in the early nineties, unemployment insurance legislation was revised thoroughly in 1995. This reduced the unconditional benefit period to 150 days with longer benefit duration up to 520 days being dependent upon participation in active labor market programs. Since 2003 maximum duration of unemployment benefit is 400 days.

Swiss studies had shown that longer passive benefit duration led to longer unemployment spells (Sheldon 2002). Therefore, strict activation had to counterbalance the negative incentives stemming from long benefit duration and a generous benefit level. Consequently the new system, in place since 1997, expanded resources devoted to active labor market policy schemes directed at reintegration into employment. Subsidized temporary employment, a scheme that tops up earnings if the unemployed accept a job that provides less net earnings than the unemployment benefit, is notable. This instrument has a good reputation as regards its effectiveness (Gerfin/Lechner/Steiger 2003, Gerfin/Lechner 2001). Parallel to changes in active measures the administrative set-up of Swiss labor market policies was modernized with regional placement offices taking charge of benefit payment, placement, monitoring job search efforts and selection of appropriate activation schemes for unemployed individuals. The performance of regional offices, which had been created in 1995, is benchmarked and partly determines budget allocation. This led to a significant increase in efficiency.

The design of labor market policies in Switzerland benefited from the fact that, due to the virtual absence of such policies before the early nineties, policy-makers did not have to take policy legacies into account but could build their system upon the OECD' recommendations for an activating labor market policy. With this efficiently managed regime of "carrots and sticks", Switzerland was able to reduce unemployment in the following period of economic recovery from 1997 onwards although long-term unemployment rose a bit. Additional expenditure on active programs was set off by savings on unemployment benefits. Hence, open unemployment is still low in Switzerland, although economic growth has been rather weak.

As regards the politics of reforms, Swiss policy-makers could rely on a general societal consensus on the legitimacy of an activating approach in 
labor market policy and a liberal labor law, but also on an efficient and economical use of public resources. Public policies in Switzerland are made in a consociational system with a strong federal element. This does not only mean devolution of power to the cantons, but also high consensus requirements at the federal level. In order to implement the national legal framework of labor market policy and the principle of activation consistently and to ensure commitment by actors at the regional level, national policy-makers relied on transparent information and independent policy evaluation.

\subsection{The Netherlands}

Compared to the Scandinavian and the liberal welfare states, the Netherlands show a different point of departure both in employment protection and in labor market policy, but also a peculiar reform path. Labor market reforms in the Netherlands were implemented over more than two decades. They can only be interpreted appropriately with reference to the severe economic crisis of the early eighties and the path-breaking Wassenaar agreement on welfare state reform, wage restraint and working time flexibility (Visser/Hemerijck 1997). This bipartite agreement between the social partners was initiated in 1982 by the Dutch government through a credible threat of intervention. In the following years several steps were undertaken to make the Dutch labor market more flexible. This resulted in collective agreements on working time flexibility and wage moderation and a removal of barriers to part-time work.

Regarding employment protection, the Netherlands had one of the most restrictive systems of dismissal protection in the early eighties. Even before labor market policies were reformed, first steps were taken to increase labor market flexibility. However, this did non concern dismissal protection but the creation of a flexible segment at the margin of the labor market. Different types of not explicitly regulated "Flex jobs" such as fixed-term contracts, temporary agency work, stand-by contracts or freelancing grew strongly (van Oorschot 2004).

Both the expansion of flexible jobs and part-time employment contributed significantly to the Dutch employment 'miracle'. However, reforming labor market regulation was also an issue in Dutch policy-making in the nine- 
ties. In 1993 the social partners agreed on a joint strategy in favor of a "New Course" that combined working time policy and regulatory issues. Three years later employers and trade unions signed an agreement on "Flexicurity" that referred to a government proposal (Camps 2004, Hemerijck 2003). It was implemented through several laws which increased labor market flexibility and provided higher employment protection for workers in the flexible segment of the Dutch labor market. Hence, it aimed at reducing the gap in regulation intensity between the core and the margin of the labor market. In 1998, new legislation lifted major restriction on temporary agency work and provided equal payment whereas the subsequent "Flexicurity" law strengthened employment security of workers with fixed-term contracts and employees of temporary work agencies in 1999.

The law stipulates that fixed-term contracts can be renewed three times in three years. After the third renewal or after an overall duration of more than three years fixed-term contracts turn into permanent ones. Temporary agency workers benefit from their contract being considered a regular one and from a phase model that binds the level of employment security to the duration of the employment relationship. Whereas employment ends with each assignment in the first 26 weeks, the consecutive phases raise employment and income security. After 26 weeks workers are covered by pension schemes and get access to job-related training. They can now claim continuation of payment in periods without assignments or in case of sickness and at least three months' fixed-term employment after 52 weeks of employment. After 18 or 36 months, a permanent contract between the agency and the worker is established. It is most notable that Dutch legislation on "flexicurity" also modified dismissal protection for the first time by reducing notice periods and streamlining administrative procedures. Dutch dismissal law is based on a dual system. On the one hand, an employer can dismiss a worker without severance pay if he is permitted to do so by the public administration. On the other hand, he can request a court to dissolve the employment contract which is possible with sufficient justification and compensatory payments. While the first option entails legal insecurity, the second one demands considerable severance pay (OECD 2004). 
Part-time work, however, expanded due to changes in private sector recruitment and growing female labor supply without public policies encouraging this type of flexible employment. It was facilitated by the existence of a universal flat-rate public pension scheme and after the strong growth of part-time employment in the eighties, certain working time and earnings thresholds were lifted: Since 1993 part-time workers are covered by the statutory minimum wage and a pro-rata entitlement to vacation bonus payments, in 1994 they were incorporated into occupational pension schemes, and in 1996 the principle of equal treatment of full- and parttime workers in labor law and collective agreements was stipulated. In the year 2000 workers were entitled to demand working time reduction or extension from their employers. As is the case with most relevant reforms in the Netherlands, these modifications were prepared through dialogue with the social partners (van Oorschot 2004, Hemerijck 2003).

Although part of the social policy reforms in the eighties also addressed unemployment benefits and lowered them, active or activating labor market policies appeared on the Dutch policy agenda much later (Visser/Hemerijck 1997, van Oorschot/Abrahamson 2003). In August 1996 the system of benefit sanctions was intensified considerably. Benefit recipients may get a reduction of their benefits if they do not follow the rules related to the benefits. In case of voluntary quits or dismissals caused by personal misconduct no benefits can be received. If unemployed persons reject training or suitable job offers, benefits are suspended or cut. Criteria defining suitable jobs were made more restrictive. A sanction rate of $36 \%$ of the average stock of benefit claims of unemployment benefit recipients is among the highest in OECD countries (Nickell/van Ours 2000). The same type of benefit sanctions exists for social assistance. These changes on the "passive" side were more important than innovation in active labor market policies. The restructuring of the benefit system with stricter rules on availability and suitability are certainly measures supporting the 'Dutch miracle' in the nineties.

After a phase of remarkable employment growth and a decline in open unemployment, reintegration of long-term unemployed and activation of non employed persons became an issue in the Netherlands (van Oorschot/Abrahamson 2003). This policy reorientation was inspired by the need to partially reduce state intervention and strengthen market forces in 
the Dutch welfare state, which was expressed in an influential paper issued by the WRR council for policy advice. "Jobs, Jobs, Jobs" were made an effective policy objective by the new social democratic-liberal government that gained power in 1994.

This implied policy reforms aimed at a better integration of low-skilled workers through low wage employment and a consistent activation strategy making benefit receipt conditional upon acceptance of active measures or job offers. This resulted in a fundamental shift away from costly, but passive labor market policies in favor of a more integration-oriented approach. Apart from stricter sanctioning, the complex system of active measures in the Netherlands was supplemented after 1994 by two important elements: on the one hand, targeted schemes to further labor market integration of the young, the low-skilled, women or migrants were expanded and became effective work tests. This also comprised subsidized employment with public or private employers as well as temporary agency placements in the public sector for the long-term unemployed. Similar measures were taken by the municipalities responsible for social assistance. On the other hand, employers' social security contributions were reduced at the bottom end of the wage scale to further demand for lowskilled labor, whereas a more generous basic tax allowance and, in 2001/02, tax benefits for both employers and employees were implemented to facilitate transitions from benefit receipt or subsidized employment to regular employment and to top up low net earnings.

While activation strategies mainly addressed the unemployed in the nineties, they were expanded to activate larger groups of inactive persons such as recipients of disability benefits, which had been used to reduce labor supply over many years. Neither resources spent on active labor market policy nor benefit levels were cut significantly, but resources were redirected towards activation, and conditions for benefit receipt made more demanding. However, in 2004, earnings-related benefits available after expiry of unemployment insurance benefits with a maximum duration of five years were abolished. Nevertheless, Dutch unemployment benefits are still quite generous.

Dutch activation strategies were complemented by a complete overhaul of the public employment service. Since 2002, all unemployed persons are 
dealt with by one-stop-shops (CWI) that are responsible for informing and assessing job seekers through profiling but are in charge of neither benefit payments nor provision of active labor market policy instruments. All active measures, including placement and more intensive consulting of job seekers, are contracted out to private service providers which are remunerated in case of successful placement, the concrete payment being dependent upon time and effort defined in the profiling procedure. A similar system exists for social assistance recipients.

The overall picture of labor market reforms in the Netherlands is one of a shift from passive to activating labor market policies in the nineties while leaving the benefit level virtually untouched but tightening conditions for benefit receipt. This helped reduce the unemployment rate and long-term unemployment. At the same time Dutch policy-makers during the nineties tried to increase labor market flexibility and overcome segmentation between the core and the margin by raising employment security of flexible jobs and moderately reducing the restrictive character of individual dismissal protection. All major reforms in the Netherlands between 1982 and the early years of the current decade were formulated and implemented in a political framework characterized by strong social partnership. However, in critical moments government could provide necessary impulses to reform and credibly threaten employers and trade unions with unilateral action or intervention. This is not only true for the initial agreement of 1982 but also for the new sequence of reforms triggered in 1993. The Dutch tripartite setting facilitated the long sequence of institutional adaptation of the labor market through package deals that provided compensation for wage moderation or welfare state retrenchment by tax concessions. The positive medium-term experience with structural reforms strengthened commitment to the reform process and therefore made further institutional changes possible (Hemerijck/Schludi 2000). Pragmatic decisionmaking was also supported by the strong position of expert committees such as the WRR that provided influential analyses and policy proposals and by the important contributions of the Central Planning Bureau (Visser/Hemerijck 1997, Hemerijck 2003). 


\subsection{Spain}

The Southern welfare state of Spain can be characterized by a sequence of reforms aiming at increased labor market flexibility through relaxation of employment protection (Bover/García-Perea/Portugal 2000, Dolado/García-Serrano/J imeno-Serrano 2002, Toharia/Malo 2000). The pattern of reforms is similar to the Dutch experience in that Spain also had to deal with a system with restrictive individual dismissal protection. This was inherited from the Franco era. Facing high unemployment, the socialist government in 1984 initiated reforms to liberalize fixed-term contracts that had been banned before. Hence, employers could expand their labor force on a temporary basis without encountering prohibitive firing costs. This resulted in a dynamic growth of fixed-term contracts for labor market outsiders or entrants, such as young people, while leaving the labor market insiders covered by dismissal protection virtually untouched. Until the mid-nineties fixed-term employment grew to about one third of all jobs in Spain. Employment growth was mainly a phenomenon of the flexible segment, whereas transitions between fixed-term and open-ended contracts remained difficult.

The second stage of reforms in employment protection addressed regulation of the core labor market. In 1994 und 1997 reforms addressed regular contracts in that they reduced severance pay for dismissed workers, made dismissals for organizational reasons easier and lowered social security contributions by 40 to $80 \%$ for two years if fixed-term contracts were turned into permanent ones or if workers were hired on a permanent basis right away. These measures aimed at easing labor market entry and making permanent contracts more accessible to younger people and older workers. They were extended to women and the long-term unemployed in 2001. For the first time, fixed-term employees were entitled to severance pay of eight days' salary for each year in employment. Temporary agency work was legalized in 1994 but regulated more restrictively in 1997. In 1999 equal treatment of permanent employees and agency workers was stipulated which slowed down further expansion of agency work.

Spanish experience shows that flexibility at the margin of the labor market helps reduce long-term unemployment by fuelling labor turnover. The share of the long-term unemployed declined from $67 \%$ to $47 \%$ between 
1987 and 1992 while the share of fixed-term employment rose from 15\% to $33 \%$. Unemployment spells of people with preceding fixed-term contracts are shorter than those of former permanent employees. Hence, former fixed-term employees are hired more often than people who had a regular contract in the past (Dolado/García-Serrano/J imeno-Serrano 2002). On the other hand fixed-term employees often receive lower wages and experience severe difficulties in transition to permanent contracts. They only have limited access to enterprise-specific further training. Liberalization of fixed-term contracts was a major tool to promote employment growth and structural adaptation in the Spanish case where reforming regular jobs was not a viable option in the early phase of the reforms. But moderate transition to a more flexible dismissal protection and reregulation of fixed-term contracts in the mid-nineties did not help overcome the dual character of the Spanish labor market completely, albeit the growth of the share of the fixed-term employed came to a halt and was even reversed in the private sector. The vast majority of young people still have fixed-term contracts, but employment growth in the late nineties mainly took place in regular jobs. As regards the effects of the reform, employment of young members of the labor force was affected in a positive way and transitions of young and older workers to regular jobs were eased. Wage differentials between open-ended and fixed-term employment disadvantaging labor market entrants have grown considerably in Spain, whereas skill-related wage dispersion in regular contracts is compressed (Hernanz/J imeno-Serrano/Kugler 2003).

Although Spain joins the Netherlands with its sequence of reforms at the margin followed by moderate modifications of the core in labor market regulation, differences are more pronounced in labor market policies (Davia et al. 2001). Benefit levels and resources spent on both active and passive instruments are clearly less generous than in the Dutch case, and only for labor market insiders with regular contracts severance payments can be considered a substitute for unemployment benefits. After an expansion of benefit levels and coverage in the second half of the eighties, replacement rates were cut in 1992/93 by the Socialist government, contribution periods extended and availability criteria defined in a stricter way. Due to the expansion of fixed-term employment this resulted in a significant decline in benefit coverage. At the same time access to unem- 
ployment assistance was restricted to persons living in household with an aggregate income of less than $75 \%$ of the national minimum wage. Until 2001 these changes resulted in a significant reduction of benefit receipt and resources spent on passive labor market policy. Unemployment and the share of the long-term unemployed went down considerably.

Activation of the unemployed in Spain was mainly inspired by EU level recommendations that provided not only a blueprint for policy design. In 2002, this provoked the conservative government to making benefit receipt conditional upon the job seeker signing an activity obligation and to impose stricter sanctions in case of unjustified benefit receipt and refusal of suitable jobs. However, this bill was withdrawn after a severe conflict with trade unions, which had not been consulted before. Implementing policies compatible to EU recommendations was also essential for Spain in order to get access to EU resources to be spent on labor market policies. About half of the limited budget devoted to active labor market policies in Spain comes from European funds. It is mainly spent on temporary employment of selected target groups such as young people, women and the long-term unemployed. Resources gained from employers and employees via contributions to the joint training fund are spent on further job-related training of employed persons, not the unemployed. There is no unlimited means-tested social assistance for those unemployed who loose their entitlement to normal unemployment benefits. Income support for the longterm unemployed is very low level and limited in time.

Referring to the politics of labor market reforms in Spain, trade unions could rely on strong insider protection due to prohibitive dismissal costs and on financial support from the state. In order to circumvent trade union resistance, a more flexible labor market could only be achieved via deregulation at the margin. However, strong growth of fixed-term employment fundamentally changed the operation of the Spanish labor market and the political constellation with a considerable part of the labor force now employed in unstable jobs. This opened the window of opportunity and made modification of dismissal protection a viable option in political terms (Dolado/García-Serrano/Jimeno-Serrano 2002). Liberalization of temporary contracts in 1984 was triggered by a situation of very high unemployment which forced insiders to make concessions, whereas subsequent reforms were facilitated by the considerable share of workers in the 
flexible segment. Most labor market reforms in Spain were formulated in trilateral talks by government, employers and trade union and often implied package deals, such as easing dismissal protection being exchanged for stricter regulation of temporary agency work. Evidence from 2002 shows that government attempts to impose certain reforms unilaterally can hardly succeed. However, due to increased spending funded by EU sources, active labor market policies that had been negligible in the past became a more prominent feature of the Spanish labor market so that policy-makers could exploit potential policy complementarities not available before.

\subsection{Germany}

As many other European continental welfare state countries, Germany produces security and wage gains for protected insiders at the cost of job loss and exclusion of outsiders. Similar to Spain and the Netherlands, Germany had restrictive employment protection legislation until the mideighties. Restrictions on fixed-term contracts and temporary work agencies were lifted through several consecutive reform steps, the first dating back to 1985. In contrast to this medium-term trend, the latest changes concerning fixed-term contracts increased regulation slightly. The most recent amendments, implemented in the context of the "Hartz-reforms" put forward by the red-green coalition, lifted almost all restrictions on temporary agency work while establishing the principle of equal treatment between agency workers and permanent staff which can only be circumvented by collective agreements on wages and working conditions. Restrictive dismissal protection provisions were hardly changed over the last decades. Minor reforms of dismissal protection raised and lowered the size threshold of firms to be exempt from restrictive dismissal protection without questioning the general system. In addition, the latest reform, in force since 2004, introduced a right of the worker to opt for severance pay instead of the right to file a suit against the employer.

As regards active and passive labor market policy, a costly system had been in place since the late sixties. It combined generous unemployment insurance benefits with a full-blown system of active labor market policy measures. As regards unemployment benefits, unemployment insurance provides for earnings-related benefits of 63 or $67 \%$ of net earnings ac- 
cording to household properties. This rate was not changed over time but maximum benefit duration was increased in the eighties so that older workers can receive earnings-related benefits for up to 32 months, whereas the younger unemployed are only entitled to 12 months. Recent reforms of reduced benefit duration in unemployment insurance have been postponed. Until the end of 2004 an earnings-related but meanstested unemployment assistance scheme was in place that provided $53 \%$ or $57 \%$ of net earnings with infinite duration.

Whereas the effectiveness of German labor market policies was never subject to any systematic evaluation until the late nineties, a paradigm shift took place over the last years. First, based on a critical evaluation of the impact of active labor market policies on individual job prospects, the design of active measures and benefits was questioned. In 2002, this resulted in legislation that moved away from permissive benefit receipt and voluntary participation in labor market schemes towards stricter activation, making benefit receipt conditional upon individual job search and participation in ALMP. However, due to severe deficits in governance and performance of the Federal Employment Agency, the "Hartz Commission", an expert commission charged with the formulation of a blueprint for ALMP reform, urged for internal reforms of the PES and a more coherent activating labor market policy. This was implemented through a sequence of bills. Apart form restructuring the PES, the most important step was the abolishment of earnings-related unemployment assistance for the longterm unemployed by "Hartz IV". It was replaced by a flat-rate benefit similar to social assistance ("Arbeitslosengeld II"). In addition, former recipients of unemployment assistance and employable social assistance claimants are being activated more consistently in the framework of local job placement agencies.

The general picture evolving in Germany after many years of piecemeal reforms is one of stricter activation being combined with moderate cutbacks in benefit generosity and eased regulation of flexible jobs while German policy-makers refrained from stronger benefit cuts and bold deregulation of the core labor market. These reforms have only been partial in character and were not substantial enough to successfully adapt the German economy to ongoing changes as is shown by the long-term rise in unemployment and the share of the long-term unemployed. Therefore, no 
stable and efficient policy combination of flexibility and security could be achieved so far. The experience of past attempts at more comprehensive reforms is mixed at best. Since German governments are relatively weak due to social partner autonomy in wage setting and the federalist jointdecision trap (Scharpf 1988) and because of lacking institutional prerequisites for social partner negotiations, tripartite talks in the "Alliance for Jobs" failed. In contrast to the Netherlands, Germany could not address massive need to reform via effective social pacts (Streeck 2003). Attempts at government-driven reforms like the Hartz package or the subsequent "Agenda 2010" were watered down by joint policy making in German federalism and a fragile political basis for reforms due to strong resistance from powerful insider groups and the lack of societal consensus (Cox 2000) despite the fact that tackling unemployment is often mentioned in the wider public as the foremost political issue. Although the need for further institutional adaptation remains urgent, the prospects of far-reaching structural reforms are vague. The German political system, characterized by a weak government facing strong interest associations, seems incapable of designing and implementing a sequence of reform steps that increases labor market adaptability effectively.

\section{Comparative Analysis: Different Paths of Re- form}

Our analysis shows different paths of labor market reforms. It makes sense to differentiate between three groups of countries: on the one hand, we have European welfare states with a low initial level of labor market regulation which was not reduced further. These countries concentrated on implementing stricter activation policies with active elements, appearing rather late in the UK with the shift to New Labor's "New Deals" and in Switzerland where active programs were designed according to OECD blueprints. In contrast, Denmark 'activated' its full-blown system of active labor market policy in the early nineties. However, whereas in the United Kingdom modest benefits were cut, they were kept intact in Denmark and in Switzerland. All countries belonging to this cluster now combine liberal labor market regulation with intense activation - but in contrast to 'liberal' UK, the 'hybrid' countries Denmark and Switzerland still provide a generous level of unemployment benefits if the unemployed comply with the requirements imposed upon them. As regards resulting labor market per- 
formance, this setting turns out to be a favorable one in terms of achieving and maintaining low unemployment and long-term unemployment, although employment growth - at a high level of employment - was less impressive. The specific lesson we can draw from the Danish and Swiss example is that of the positive effects of low employment protection on the dynamism of the labor market. If a liberal regime of employment protection is combined with institutions that support income and reemployment security, one can obtain a well-functioning employment system without dismantling the welfare state.

--- Table 3 about here ---

The third group consists of the countries that had a high level of EPL at the outset, i.e. the countries in continental and Southern Europe (the Netherlands, Germany and Spain) but also Sweden. Initial reforms of EPL in the eighties and early nineties increased flexibility at the margin through lifting restrictions on fixed-term contracts and temporary agency work in order to create additional flexible jobs and increase overall labor market flexibility. However, at that point in time, individual dismissal protection applicable to regular jobs was left untouched. The next wave of reforms raised the level of job protection for workers in flexible jobs while moderately reducing the level of individual dismissal protection. This can be interpreted as a reaction to strong growth of the flexible segment and increasingly dual character of these labor markets. Nevertheless, labor market insiders were not affected by considerable deregulation. Transitions between the margin and the core of the labor market are still more difficult than in other countries.

With respect to labor market policy, these countries followed similar paths. The common policy shift from costly but fairly passive labor market policies to stricter activation was implemented quite early in the midnineties in the Netherlands and about a decade later in Germany and Sweden. Benefits for the unemployed were essentially left untouched in the Netherlands. Transfers to the German long-term unemployed were reduced recently, whereas in Sweden benefit duration was expanded with benefit levels being cut slightly. In Spain, an expansion of benefits in the 1980s was followed by benefit cuts in the early nineties. So we see convergence towards activation policies with stricter monitoring of jobs 
search, more frequent sanctions and more restrictive availability criteria, but no significant reductions of benefit levels. Since less permissive benefit systems make receipt of income out of work less convenient, jobseekers tend to make concessions regarding the wage level of jobs offered. However, even though EPL was eased over the last decade, flexibility of the labor market is so insufficient in these countries that the potential for the creation of additional jobs available for 'activated' jobseekers is still limited.

\section{--- Table 4 about here}

Our analysis could not provide clear-cut evidence on strategic policymaking using political and economic complementarities between labor market regulation and labor market policies in the sense of a close sequential or simultaneous coupling. But in a longer-term perspective we can see that countries with strong social partner institutions benefit from their capacity to identify needs for reform and to agree on appropriate remedy. 'Liberal' welfare regimes have strong built-in labor market adaptability due to the strength of market forces as both EPL and unemployment benefits are weak. Increasing labor market adaptability is a more urgent need for Scandinavian, continental and southern welfare states with stronger employment protection and/or more generous unemployment benefits. With hindsight we can argue that those countries were more successful in creating a more adaptable labor market, that could rely on effective capacities to manage policy complementarities: during the decisive years under scrutiny, in Denmark and the Netherlands, there was a strong political leadership that could mobilize societal support and rely on cooperative social partner relations and influential policy advice. This does not mean, however, that all reforms were implemented smoothly. Regarding Switzerland we can point at a strong consociational system.

However, taking a closer look at "successful" models we can see that they rely on preconditions which are not easily transferable. Low EPL in combination with high benefit levels constitutes the Danish flexibility-security nexus, which in its current version has already been in place since the late 1960s apart from the recent emphasis on activation. Such a system is easier to achieve if countries never introduced strict EPL, which is hard to abolish later on. The same holds for the 'hybrid' Swiss model where pre- 
existing 'liberal' EPL was supplemented by unemployment benefits and effective activation consistent with OECD recommendations. This was facilitated by the virtual absence of labor market policies prior to this reform. In contrast to these experiences, acceptance of a more flexible regime of labor market regulation and a strict activation strategy accompanied by benefit cuts remains a delicate issue in continental and southern European countries. Here the demand for capacities to manage policy complementarities is most pronounced since labor market insiders benefit from the status quo and can oppose policies that imply short-term losses for them. Thus, policy makers have to design packages that are feasible in political terms. And successful settings might erode as is shown by the most recent developments in the Netherlands.

\section{Conclusion}

Our analysis shows how employment protection legislation, active and passive labor market policies were redesigned in selected European welfare states over the last decade. It suggests that labor market adaptability benefits from, first, relaxing EPL and, second, from introducing activating elements in labor market policies, whereas maintaining a high benefit level does not seem to be incompatible with lowering unemployment. The challenges countries faced, however, were uneven. We can see that countries departed from different starting points and embarked on diverging paths of reform although all of them tried to ease EPL and to introduce activating elements into labor market policy. A high level of labor market adaptability was achieved in the 'liberal' system of the UK and the 'hybrid' models of Denmark and Switzerland. These countries benefited from the absence of strict EPL and a considerable redesign of labor market policies. Whereas in the UK unemployment benefits are fairly limited, Denmark and Switzerland maintained a generous benefit system while making access more demanding. While Denmark shifted from a passive labor market policy regime to an activating one via a sequence of fine-tuning, the UK and Switzerland introduced active and activating elements much later. Both 'hybrid' models could rely on strong consociational or corporatist arrangements so that institutional adaptation was relatively smooth.

To avoid conflicts with insiders, countries that started with stricter EPL such as Germany, the Netherlands and Spain, first introduced flexibility at 
the margin and subsequently deregulated the core to a certain extent while increasing employment protection in the flexible segment. Activation strategies were also implemented in these countries, but since flexibility of the labor market is only limited, economic success and political acceptance of activation strategies is more disputed in these countries. Political support for more far-reaching policy reforms is fragile due to strong labor market segmentation and limited short-term effects of reforms. So the profound changes required stress the demand for capacities to manage policy complementarities in economic and political terms. This was only partially successful and viable over a limited period of time if we refer to the Dutch experience with social pacts or the government-driven Hartz reforms in Germany. Since the success of activation depends on labor market flexibility in terms of regulation and wages, continental and southern countries still face considerable need for reform. In these countries, the transition to a more adaptable labor market seems difficult, given the discrepancy between the extent of reforms needed and strong path dependence reinforced by insider opposition so that government capacities and social partnership are crucial for designing reforms that exploit complementarities in a way that sufficient support can be generated. In these cases it might be viable to combine strict activation with maintaining higher benefit levels in order to make deregulation more acceptable to insiders. This requires strong political leadership, a general understanding of societal objectives and a certain level of trust between social partners (and/or political actors) which allows for employment protection to be reduced while other security mechanisms are recalibrated. 


\section{References}

Andersen, Jørgen Goul. "Denmark: From the Edge of the Abyss to a Sustainable Welfare State". Europe's New State of Welfare. Ed. by Jørgen Goul Andersen, Jochen Clasen, Wim van Oorschoot and Knut Halvorsen. Bristol 2002. 143-162. (2002a).

Andersen, Jørgen Goul. “Work and Citizenship: Unemployment and Unemployment Policies in Denmark, 1980-2000". Changing labor Markets, Welfare Policies and Citizenship. Ed. by Jørgen Goul Andersen and Per H. Jensen. Bristol 2002. 59-85. (2002b).

Arts, Wil, and J ohn Gelissen. Three Worlds of Welfare Capitalism or More? A State-of-the-art report. J ournal of European Social Policy 12 (2) 2002. 137-158.

Auer, Peter. Employment Revival in Europe, Geneva 2000.

Auer, Peter/Cazes. "The resilience of the long-term employment relationship". Employment stability in an age of flexibility. Ed. by Peter Auer and Sandrine Cazes. Genf 2003. 22-58.

Benner, Mats, and Torben Bungaard Vad. "Sweden and Denmark: Defending the Welfare State". Welfare and Work in the Open Economy. Ed. by Fritz W. Scharpf and Vivian A. Schmidt. Oxford 2000. Vol. 2, 399-466.

Björklund, Anders: “Going Different Ways: Labor Market Policy in Denmark and Sweden". Why Deregulate Labor Markets? Ed. by Gøsta Esping-Andersen and Marino Regini. Oxford 2000. 148-180.

Blanchard, Olivier, and J ustin Wolfers. "The Role of Shocks and Institutions in the Rise of European Unemployment: the aggregate evidence". The Economic J ournal 110, 2000, C1-C33.

Boeri, Tito, José I gnazio Conde-Ruiz and Vincenzo Galasso. Protecting Against Labor Market Risk: Employment Protection or Unemployment Benefits. IZA Discussion Paper 834, Bonn 2003.

Bover, Olympia, Pilar García-Perea and Pedro Portugal. “Labor Market Outliers: Lessons from Portugal and Spain”. Economic Policy, 2000. 379412.

Calmfors, Lars, Anders Forslund and Maria Hemström. “Does active labor market policy work? Lessons from the Swedish experiences". Swedish Economic Policy Review (85) 2001. 61-124.

Camps, Maarten. Increasing Adaptability of Workers and Enterprises, Paper presented at the $1^{\text {st }}$ Thematic Review Seminar of the European Employment Strategy, Brussels, 21st September 2004. 
Clasen, Jochen, J on Kvist and Wim van Oorschot. "On condition of work: increasing work requirements in unemployment compensation schemes". Nordic Welfare States in the European Context. Ed. by Mirkko Kautto et al. London 2001. 198-231.

Coe, David T., and Dennis J. Snower. Policy complementarities: the case for fundamental labor market reform. CEPR Discussion Paper 1585. London 1997.

Cox, Robert H. "From safety net to trampoline: labor market activation in the Netherlands and Denmark". Governance 11 (4) 1998. 397-414.

Cox, Robert H. "The Social Construction of an Imperative: Why Welfare Reform Happened in Denmark and the Netherlands but Not in Germany". World Politics 53 (3) 2001. 463-98.

Davia Maria A., Carlos García-Serrano, Virginia Hernanz, Miguel A. Malo and Luis Toharía. "Do active labor market policies matter in Spain?" Labor Market Policy and Unemployment. Ed. by Jaap de Koning and Hugh Mosley: Cheltenham 2001. 137-160.

Dolado, Juan J ., Carlos García-Serrano und J uan F. J imeno-Serrano. "Drawing Lessons from the Boom of Temporary J obs in Spain". The Economic J ournal. (112) 2002. 270-295.

Dolton, Peter, und Donal O'Neill. The Long-Run Effects of Unemployment Monitoring. National University of Ireland. Maynooth 1997.

Dorey, Peter. "Britain in the 1990s: The Absence of Policy Concertation". Policy Concertation and Social Partnership in Western Europe. Lessons for the $21^{\text {st }}$ Century. Ed. by Suzanne Berger and Hugh Compston. New York und Oxford 2002. 63-76.

Ebbinghaus, Bernhard, and Anke Hassel. "Striking Deals: The Role of Concertation in the Reform of the Welfare State". J ournal of European Public Policy 7 (1) 2000. 44-62.

Esping-Andersen, Gøsta. The Three Worlds of Welfare Capitalism. Cambridge 1990.

Esping-Andersen, Gøsta, and Marino Regini (Eds.): Why Deregulate Labor Markets? Oxford 2000.

European Commission. Employment in Europe 2004. Recent Trends and Prospects. Brussels 2004.

Ferrera, Maurizio. “The 'Southern Model' of Welfare in Social Europe”. Journal of European Social Policy 6 (1) 1996. 17-37.

Gangl, Markus. "Unemployment Benefits as a Search Subsidy: New Evidence on Duration and Wage Effects of Unemployment Insurance". WZB Discussion Paper FSI 208, Berlin 2002. 
Gerfin, Michael and Michael Lechner. A microeconometric evaluation of active labor market policy in Switzerland. CEPR Discussion Paper 2993. London 2001.

Gerfin, Michael, Michael Lechner and Heide Steiger. Does subsidised temporary employment get the unemployed back to work? Universität Bern Volkswirtschaftliches I nstitut. Bern 2003.

Hassel, Anke. The Politics of Social Pacts. British J ournal of Industrial Relations 41 (4) 2003. 707-726.

Heckman, James. Flexibility and J ob Creation: Lessons from Germany. NBER Working Paper 9194, September 2002.

Hemerijck, Anton. „A Paradoxical Miracle: The Politics of Coalition Government and Social Concertation in Dutch Welfare Reform“. Konzertierung, Verhandlungsdemokratie und Reformpolitik im Wohlfahrtsstaat, Ed. by Sven J ochem and Nico A. Siegel. Opladen 2003. 232-270.

Hemerijck, Anton C., and Martin Schludi. "Sequences of Policy Failures and Effective Policy Responses", Welfare and Work in the Open Economy. Ed. by Fritz W. Scharpf and Vivian A. Schmidt. Oxford 2000. Vol. 1. $125-228$.

Hernanz, Virginia, Juan F. Jimeno-Serrano and Adriana Kugler. Employment Consequences of Restrictive Permanent Contracts: Evidence from Spanish Labor Market Reforms. CEPR Discussion Paper 3724. London 2003.

Immergut, Ellen. Health Politics. Interests and Institutions in Western Europe. Cambridge 1992.

Jochem, Sven. „Konzertierung und Parteienwettbewerb: Das schwedische Modell im Wandel“. Konzertierung, Verhandlungsdemokratie und Reformpolitik im Wohlfahrtsstaat, Ed. by Sven J ochem and Nico A. Siegel. Opladen 2003. 271-310. (2003a).

Jochem, Sven: „Nordic Corporatism and Welfare State Reforms: Denmark and Sweden Compared". Renegotiating the Welfare State. Flexible Adjustment through Corporatist Concertation. Ed. by Frans van Waarden and Gerhard Lehmbruch. London 2003. 114-141. (2003b).

Jochem, Sven. "Veto Players or Veto Points? The Politics of Welfare State Reforms in Europe. Paper presented at the 2003 Annual Meeting of the American Political Science Association. University of Konstanz 2003. (2003c).

Knuth, Matthias, Oliver Schweer and Sabine Siemes. Drei Menüs - und kein Rezept? Dienstleistungen am Arbeitsmarkt in Großbritannien, in den Niederlanden und in Dänemark. Friedrich Ebert Stiftung. Bonn 2004. 
Kvist, Jon. "Changing rights and obligations in unemployment insurance". Social Security in the Global Village. Eds. Roland Sigg and Christina Behrendt. New Brunswick 2002. 227-245.

Layard, Richard, Stephen Nickell and Richard Jackman. Unemployment. Macroenconomic Performance and the Labor Market. Oxford 1991.

Lindbeck, Assar, and Dennis J. Snower. The Insider-Outsider Theory of Employment and Unemployment. Cambridge Mass. 1988.

Madsen, Per K. The Danish model of flexicurity - A paradise with some snakes. European Foundation for the Improvement of Living and Working Conditions. Dublin 2002 (2002a).

Madsen, Per K. 'Flexicurity' through labor market policies and institutions in Denmark". Employment stability in an age of flexibility. Ed. by Peter Auer and Sandrine Cazes. Genf 2002. 59-105 (2002b).

Madsen, Per K. “The Danish model of 'flexicurity': Experiences and lessons". Transfer 10 (2) 2004. 187-207.

Madsen, Per K. "Labor Market Flexibility and Social Protection in European Welfare States- Contrasts and Similarities". Paper presented to the Conference 'Transitions and Risks: New Directions in Social Policy'. Centre for Public Policy, University of Melbourne 2005.

Martin, John P., and David Grubb. What Works and for Whom: A Review of OECD Countries' Experiences with Active Labor Market Policies. Swedish Economic Policy Review 8 (2) 2001. 9-56.

Nickell, Stephen, and J an van Ours. "The Netherlands and the United Kingdom: a European unemployment miracle?" Economic Policy, April 2000. 137-180.

OECD. OECD Employment Outlook 1999. Paris 1999.

OECD. OECD Employment Outlook 2003. Paris 2003.

OECD. OECD Employment Outlook 2004. Paris 2004.

OECD. OECD Employment Outlook 2005. Paris 2005.

Orszag, J. Michael and Dennis J. Snower. The Anatomy of Policy Complementarities. IZA Discussion Paper 41, Bonn 1999.

Pierson, Paul. "Increasing returns, path dependence, and the study of politics". American Political Science Review 94 (2) 2000. 251-267.

Scharpf, Fritz W. "The J oint Decision Trap. Lessons from German Federalism and European Integration". Public Administration 66 (3) 1988. 239278.

Saint-Paul, Gilles. "The political economy of employment protection". J ournal of Political Economy 110 (3) 2002. 672-704. 
Saint-Paul, Gilles. Why are European Countries Diverging in Their Unemployment Experience? IZA Discussion Paper N 1066, March 2004.

Scharpf, Fritz W. “Economic Changes, Vulnerabilities, and Institutional Capabilities". Welfare and Work in the Open Economy. Ed. by Fritz W. Scharpf and Vivian A. Schmidt. Oxford 2000. Vol. 1, 21-124.

Sheldon, George. "Unemployment and unemployment policy in Switzerland". Europe's New State of Welfare. Ed. by Jørgen Goul Andersen, J ochen Clasen, Wim van Oorschoot and Knut Halvorsen. Bristol 2002. 217-232.

Straubhaar, Thomas und Heinz Werner: „Arbeitsmarkt Schweiz - ein Erfolgsmodell?" Mitteilungen aus der Arbeitsmarkt- und Berufsforschung 36 (1) 2003, 60-76

Streeck, Wolfgang. From State Weakness as Strength to State Weakness as Weakness: Welfare Corporatism and the Private Use of the Public Interest. MPIfG Working Paper 03/2. Cologne 2003.

Toharia, Luis, and Miguel A. Malo. "The Spanish Experiment: Pros and Cons of Flexibility at the Margin". Why Deregulate Labor Markets?. Ed. by Gøsta Esping-Andersen and Marino Regini. Oxford 2000. 307-341.

Van Oorschoot, Wim. "Flexible work and flexicurity policies in the Netherlands: Trends and experiences". Transfer 10 (2) 2004. 208-225.

Van Oorschoot, Wim, and Peter Abrahamson. "The Dutch and Danish Miracles Revisited: A Critical Discussion of Activation Policies in Two Small Welfare States". Social Policy \& Administration 37 (3) 2003. 288-304.

Visser, Jelle, and Anton Hemerijck. „A Dutch Miracle': J ob Growth, Welfare Reform and Corporatism in the Netherlands. Amsterdam 1997.

Wilthagen, Ton, and Martijn van Velzen. The road towards adaptability, flexibility and security. Discussion Paper presented at the $1^{\text {st }}$ Thematic Review Seminar of the European Employment Strategy, Brussels, 21st September 2004. 


\section{Appendix}

Table 1: Changes in EPL, ALMP and Unemployment Benefits

Sources: OECD Employment Outlook, various editions; OECD Benefits and Wages, OECD Benefit Systems and Work Incentives.

\begin{tabular}{|c|c|c|c|c|c|c|c|}
\hline & $\begin{array}{l}\text { Den- } \\
\text { mark }\end{array}$ & Sweden & $\begin{array}{l}\text { United } \\
\text { Kingdom }\end{array}$ & Switzerland & $\begin{array}{l}\text { Nether- } \\
\text { lands }\end{array}$ & Spain & $\begin{array}{l}\text { Ger- } \\
\text { many }\end{array}$ \\
\hline \multicolumn{8}{|c|}{ Employment Protection Legislation } \\
\hline \multicolumn{8}{|c|}{ Fixed-term contracts } \\
\hline Late $1980 \mathrm{~s}$ & 2,3 & 2,7 & 0,0 & 1,3 & 1,5 & 2,0 & 3,5 \\
\hline Late $1990 \mathrm{~s}$ & 2,3 & 1,8 & 0,0 & 1,3 & 0,8 & 2,5 & 1,8 \\
\hline 2003 & 2,3 & 1,8 & 0,3 & 1,3 & 0,8 & 3,0 & 1,8 \\
\hline \multicolumn{8}{|c|}{ Temporary work agencies } \\
\hline Late $1980 \mathrm{~s}$ & 4,0 & 5,5 & 0,5 & 1,0 & 3,3 & 5,5 & 4,0 \\
\hline Late 1990s & 0,5 & 1,5 & 0,5 & 1,0 & 1,6 & 4,0 & 2,8 \\
\hline 2003 & 0,5 & 1,5 & 0,5 & 1,0 & 1,6 & 4,0 & 1,8 \\
\hline \multicolumn{8}{|c|}{ Dismissal Protection } \\
\hline Late $1980 \mathrm{~s}$ & 1,5 & 2,9 & 0,9 & 1,2 & 3,1 & 3,9 & 2,6 \\
\hline Late $1990 \mathrm{~s}$ & 1,5 & 2,9 & 0,9 & 1,2 & 3,1 & 2,6 & 2,7 \\
\hline 2003 & 1,5 & 2,9 & 1,1 & 1,2 & 3,1 & 2,6 & 2,7 \\
\hline \multicolumn{8}{|c|}{ Overall strictness of regulation } \\
\hline Late 1980s & 2,3 & 3,5 & 0,6 & 1,1 & 2,7 & 3,8 & 3,2 \\
\hline Late 1990s & 1,4 & 2,2 & 0,6 & 1,1 & 2,1 & 2,9 & 2,5 \\
\hline 2003 & 1,4 & 2,2 & 0,6 & 1,1 & 2,1 & 3,1 & 2,2 \\
\hline \multicolumn{8}{|c|}{ Expenditure on active labor market policy in \% of GDP } \\
\hline 1993 & 1,97 & 2,98 & 0,57 & 0,39 & 1,24 & 0,53 & 1,62 \\
\hline 1998 & 1,89 & 2,01 & 0,34 & 0,70 & 1,76 & 0,72 & 1,27 \\
\hline 2003 & 1,74 & 1,29 & 0,53 & 0,77 & 1,83 & 0,72 & 1,14 \\
\hline Change in PP & $-0,23$ & $-1,69$ & $-0,04$ & 0,38 & 0,59 & 0,19 & $-0,48$ \\
\hline \multicolumn{8}{|c|}{ Expenditure on passive labor market policy in \% of GDP } \\
\hline 1993 & 5,49 & 2,77 & 1,60 & 1,64 & 2,87 & 3,59 & 2,59 \\
\hline 1998 & 3,74 & 1,91 & 0,63 & 1,07 & 3,14 & 1,64 & 2,29 \\
\hline 2003 & 2,68 & 1,22 & 0,37 & 1,02 & 1,86 & 1,48 & 2,31 \\
\hline Change in PP & $-2,81$ & $-1,55$ & $-1,23$ & $-0,63$ & $-1,01$ & $-2,11$ & $-0,28$ \\
\hline \multicolumn{8}{|c|}{ Unemployment benefit generosity (gross replacement rates for different earnings) } \\
\hline 1993 & 51 & 28 & 19 & 30 & 53 & 32 & 28 \\
\hline 1997 & 62 & 27 & 18 & 34 & 52 & 31 & 26 \\
\hline 2001 & 51 & 24 & 17 & 38 & 53 & 31 & 28 \\
\hline \multicolumn{8}{|c|}{$\begin{array}{l}\text { Net replacement rates of unemployment benefits, average production worker, single, first } \\
\text { month of unemployment }\end{array}$} \\
\hline 1997 & 62 & 72 & 50 & 73 & 75 & 76 & 60 \\
\hline 1999 & 63 & 71 & 46 & 81 & 82 & 74 & 60 \\
\hline 2002 & 59 & 81 & 45 & 72 & 71 & 70 & 61 \\
\hline \multicolumn{8}{|c|}{$\begin{array}{l}\text { Net replacement rates of unemployment benefits, average production worker, single, } \mathbf{6 0}^{\text {th }} \\
\text { month of unemployment }\end{array}$} \\
\hline 1997 & 48 & 58 & 50 & 61 & 60 & 25 & 54 \\
\hline 1999 & 60 & 54 & 46 & 54 & 60 & 23 & 54 \\
\hline 2002 & 50 & 51 & 45 & 51 & 58 & 27 & 61 \\
\hline
\end{tabular}

Sources: OECD Employment Outlook, various issues; OECD Benefit Systems and Work Intensives/OECD Benefits and Wages, various issues. 
Table 2: Indicators of Labor Market Performance

\begin{tabular}{|c|c|c|c|c|c|c|c|}
\hline Country & Denmark & Sweden & $\begin{array}{c}\text { United } \\
\text { Kingdom }\end{array}$ & Switzerland & $\begin{array}{l}\text { Nether- } \\
\text { lands }\end{array}$ & Spain & Germany \\
\hline \multicolumn{8}{|c|}{ Standardized unemployment rate, \% of total labor force } \\
\hline Average 1992-94 & 8,6 & 8,0 & 9,7 & 3,6 & 6,1 & 17,8 & 7,5 \\
\hline Average 2002-04 & 5,2 & 5,6 & 4,9 & 3,9 & 3,7 & 11,1 & 8,9 \\
\hline Change in PP & $-3,4$ & $-2,4$ & $-4,8$ & 0,3 & $-2,4$ & $-6,6$ & 1,5 \\
\hline \multicolumn{8}{|c|}{ Employment/population ratio, \% of persons aged 15-64 years } \\
\hline Average 1992-94 & 74,2 & 72,4 & 68,0 & 80,7 & 63,6 & 46,3 & 65,8 \\
\hline Average 2002-04 & 75,8 & 74,2 & 72,8 & 78,1 & 73,7 & 60,7 & 65,1 \\
\hline Change in PP & 1,6 & 1,8 & 4,8 & $-2,6$ & 10,1 & 14,4 & $-0,7$ \\
\hline \multicolumn{8}{|c|}{ Share of the long-term unemployed, \% of total unemployment } \\
\hline Average 1992-94 & 28,0 & 12,0 & 41,1 & 21,9 & 43,8 & 51,2 & 39,0 \\
\hline Average 2002-04 & 20,7 & 19,2 & 22,5 & 27,2 & 29,5 & 39,2 & 49,9 \\
\hline Change in PP & $-7,3$ & 7,2 & $-18,6$ & 5,3 & $-14,3$ & $-12,0$ & 10,9 \\
\hline \multicolumn{8}{|c|}{ Average tenure, years } \\
\hline 1992 & 8,8 & n.a. & 8,1 & n.a. & 8,9 & 9,9 & 10,7 \\
\hline 2000 & 8,3 & 11,5 & 8,2 & n.a. & 9,1 & 10,1 & 10,5 \\
\hline Change in \% & $-5,7$ & 8,5 & 1,2 & n.a. & 2,2 & 2,0 & $-1,9$ \\
\hline
\end{tabular}

Source: OECD Employment Outlook and OECD Labor Force Statistics, various issues. For tenure: Auer/Cazes 2003, for Sweden change from 1995. 
Table 3: Major Reforms in Selected Countries

\begin{tabular}{|c|c|c|c|c|}
\hline Country & $\begin{array}{c}\text { Active Labor Market } \\
\text { Policy }\end{array}$ & $\begin{array}{l}\text { Unemployment } \\
\text { Benefit System }\end{array}$ & Activation & Employment Protection \\
\hline Denmark & $\begin{array}{l}\text { After } 1994 \text { creation of } \\
\text { paid leave schemes and } \\
\text { expansion of early retire- } \\
\text { ment (phased out after } \\
1996 \text { ) } \\
\text { After } 2002 / 03 \text { streamlin- } \\
\text { ing of active labor market } \\
\text { policy instruments }\end{array}$ & $\begin{array}{l}\text { Since } 1994 \text { reductions of } \\
\text { maximum duration of UI benefits } \\
\text { from } 9.5 \text { to } 4 \text { years in } 1999 \text {, but not } \\
\text { of benefit level }\end{array}$ & $\begin{array}{l}\text { Since } 1994 / 95 \text { progressive strictness of activa- } \\
\text { tion, mandatory participation in activating pro- } \\
\text { grams after } 3 \text { years of unemployment; job-search } \\
\text { contracts } \\
1999 \text { early activation after } 1 \text { year; activation for } \\
\text { UA recipients } \\
\text { After } 2002 \text { integration of activation for UI and } \\
\text { UA claimants, activation from first day of unem- } \\
\text { ployment }\end{array}$ & No changes except liberalization of TWA in 1995 \\
\hline Sweden & $\begin{array}{l}\text { Early 90s: expansion of } \\
\text { program participation } \\
\text { Late 90s: cut in partici- } \\
\text { pant inflow and resources }\end{array}$ & $\begin{array}{l}\text { 1994-97: reduction of UI benefit } \\
\text { level; introduction of waiting days } \\
\text { 2000: optional extension of benefit } \\
\text { period to } 600 \text { days }\end{array}$ & $\begin{array}{l}\text { 2000: 'activation guarantee' } \\
\text { 2001: stricter availability criteria }\end{array}$ & $\begin{array}{l}\text { 1993: TWA permitted } \\
\text { 1994: changes in dismissal protection, withdrawn } \\
\text { in 1995 } \\
\text { 1997: liberalization of FTC }\end{array}$ \\
\hline $\begin{array}{l}\text { United } \\
\text { Kingdom }\end{array}$ & $\begin{array}{l}\text { Negligible role until intro- } \\
\text { duction of New Deal } \\
\text { programs in } 1998\end{array}$ & $\begin{array}{l}\text { Reduction of benefit generosity } \\
\text { and permissiveness } \\
\text { 1996: Jobseekers' Allowance }\end{array}$ & $\begin{array}{l}\text { 1987: activation through 'Restart program' } \\
\text { 1988: Family Credit } \\
\text { 1996: stricter activation via 'Jobseekers' Allow- } \\
\text { ance' } \\
\text { 1998: 'New Deal' (workfare) } \\
\text { 1999: Working Families' Tax Credit } \\
\text { 2003: Working Tax Credit }\end{array}$ & $\begin{array}{l}\text { 1999: re-introduction of statutory minimum wage } \\
\text { after abolition of Wage Councils in 1993; no sub- } \\
\text { stantial changes of EPL, but shorter trial periods in } \\
\text { 2000, maximum duration of FTC reduced to four } \\
\text { years in } 2002\end{array}$ \\
\hline Switzerland & $\begin{array}{l}\text { Increase in resources over } \\
\text { the nineties }\end{array}$ & $\begin{array}{l}\text { 1995: reduced duration of uncondi- } \\
\text { tional entitlement to } 150 \text { days; } \\
\text { extended benefit duration ( } 520 \\
\text { days) depending on ALMP partici- } \\
\text { pation; maximum duration reduced } \\
\text { to } 400 \text { days in } 2003\end{array}$ & Since $1995 / 97$ stricter activation regime & No substantial changes \\
\hline Netherlands & $\begin{array}{l}\text { Expansion of targeted } \\
\text { subsidized employment } \\
\text { after } 1994\end{array}$ & 2004: abolition of UA & $\begin{array}{l}\text { 1996: Activation through stricter sanctioning } \\
\text { 2001: tax benefits for low-wage earners } \\
\text { 2002: Reform of public employment services }\end{array}$ & $\begin{array}{l}\text { 1993-96: Removal of several thresholds relevant } \\
\text { for part-time work } \\
\text { 1998: Liberalization of TWA } \\
\text { 1999: Higher employment security of FTC and } \\
\text { TWA workers ("flexicurity") accompanied by } \\
\text { moderate reform of dismissal protection }\end{array}$ \\
\hline
\end{tabular}




\begin{tabular}{|c|c|c|c|c|}
\hline Country & $\begin{array}{l}\text { Active Labor Market } \\
\text { Policy }\end{array}$ & $\begin{array}{l}\text { Unemployment } \\
\text { Benefit System }\end{array}$ & Activation & Employment Protection \\
\hline Spain & $\begin{array}{l}\text { Modest increase in re- } \\
\text { sources funded mainly } \\
\text { from EU funds }\end{array}$ & $\begin{array}{l}\text { Cut of replacement rates in } \\
1992 / 93\end{array}$ & 1992/93: stricter availability criteria & $\begin{array}{l}\text { 1984: liberalization of FTC, tightened in } 1994 \text { and } \\
2001 \\
1994 \text { TWA permitted } \\
1994 \text { less restrictive procedural requirements in } \\
\text { dismissal protection } \\
1997 \text { reduction of maximum compensation for } \\
\text { unfair dismissal }\end{array}$ \\
\hline Germany & 2003: Hartz I to III & $\begin{array}{l}\text { 2005: Abolition of UA ("Hartz } \\
\text { IV") }\end{array}$ & $\begin{array}{l}\text { 2002: Shift towards activation ("Job Aqtiv"), } \\
\text { furthered by subsequent Hartz reforms (2003- } \\
\text { 05) }\end{array}$ & $\begin{array}{l}\text { 1985: FTC without specific reason } \\
\text { 1994: relaxation of TWA provisions } \\
\text { 1996: liberalization of FTC and TWA, higher size } \\
\text { threshold for dismissal protection, lowered again } \\
\text { in 1999 } \\
\text { 2002/03: abolition of major restrictions on TWA + } \\
\text { equal pay or collective agreements } \\
\text { 2004 higher size threshold in dismissal protection }\end{array}$ \\
\hline
\end{tabular}

Note: TWA means temporary work agencies, FTC fixed-term contracts, UI unemployment insurance, UA unemployment assistance. Source: Compilation by authors based on information from country studies; OECD 2004. 
Table 4: Mapping Labor Market Reforms and Outcomes

\begin{tabular}{|c|c|c|c|c|c|c|c|}
\hline \multirow[t]{2}{*}{ Country } & \multicolumn{3}{|c|}{ Labor Market Policies } & \multirow[t]{2}{*}{$\begin{array}{l}\text { Employment } \\
\text { Protection }\end{array}$} & \multicolumn{3}{|c|}{$\begin{array}{c}\text { Labor Market } \\
\text { Outcomes }\end{array}$} \\
\hline & Active & Passive & $\begin{array}{l}\text { Activa- } \\
\text { tion }\end{array}$ & & \begin{tabular}{|c|} 
Unem- \\
ployment
\end{tabular} & $\begin{array}{c}\text { Employ- } \\
\text { ment }\end{array}$ & \begin{tabular}{|l} 
Long- \\
Term \\
Unem- \\
ployment
\end{tabular} \\
\hline Denmark & 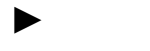 & 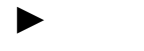 & $\boldsymbol{\Delta} \boldsymbol{\Delta}$ & $>$ & $\nabla$ & $\nabla$ & $\nabla$ \\
\hline Sweden & $\Delta->\nabla$ & 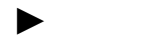 & $\mathbf{\Delta}$ & Margin $\nabla$ & $\nabla$ & $\nabla$ & $\mathbf{\Delta}$ \\
\hline United Kingdom & $\mathbf{\Delta}$ & $\nabla$ & $\Delta \boldsymbol{\Delta}$ & $\boldsymbol{\Delta A}$ & $\nabla$ & $\nabla$ & $\nabla$ \\
\hline Switzerland & $\Delta$ & $\Delta$ & $\Delta \boldsymbol{\Delta}$ & $\nabla$ & $\nabla$ & $\nabla$ & $\Delta$ \\
\hline Netherlands & $\mathbf{\Delta}$ & $\nabla$ & $\Delta \Delta$ & $\begin{array}{l}\text { Margin } \boldsymbol{\nabla} \\
->\text { Margin } \boldsymbol{\Delta}+ \\
\text { Core } \boldsymbol{\nabla} \\
\end{array}$ & $\nabla$ & $\mathbf{\Delta}$ & $\nabla$ \\
\hline Spain & $\mathbf{\Delta}$ & $\nabla$ & $\mathbf{\Delta}$ & $\begin{array}{l}\text { Margin } \boldsymbol{\nabla} \\
->\text { Margin } \boldsymbol{\Delta}+ \\
\text { Core } \boldsymbol{\nabla}\end{array}$ & $\nabla$ & $\mathbf{\Delta}$ & $\nabla$ \\
\hline Germany & $\Delta->\nabla$ & $\nabla$ & $\Delta(\Delta)$ & Margin $\nabla$ & $\Delta$ & $>$ & $\Delta$ \\
\hline
\end{tabular}

Source: Compilation by authors. 


\section{In dieser Reihe sind zuletzt erschienen Recently published}

\begin{tabular}{|c|c|c|c|}
\hline No. & Author(s) & Title & Date \\
\hline $1 / 2004$ & $\begin{array}{l}\text { Bauer, Th. K., } \\
\text { Bender, St., } \\
\text { Bonin, H. }\end{array}$ & $\begin{array}{l}\text { Dismissal Protection and Worker Flows in } \\
\text { Small Establishments }\end{array}$ & 7/2004 \\
\hline 2/2004 & $\begin{array}{l}\text { Achatz, J., } \\
\text { Gartner, H., } \\
\text { Glück, T. }\end{array}$ & $\begin{array}{l}\text { Bonus oder Bias? Mechanismen geschlechts- } \\
\text { spezifischer Entlohnung }\end{array}$ & 7/2004 \\
\hline $3 / 2004$ & $\begin{array}{l}\text { Andrews, M., } \\
\text { Schank, Th., } \\
\text { Upward, R. }\end{array}$ & $\begin{array}{l}\text { Practical estimation methods for linked } \\
\text { employer-employee data }\end{array}$ & $8 / 2004$ \\
\hline $4 / 2004$ & $\begin{array}{l}\text { Brixy, U., } \\
\text { Kohaut, S., } \\
\text { Schnabel; C. }\end{array}$ & $\begin{array}{l}\text { Do newly founded firms pay lower wages? } \\
\text { First evidence from Germany }\end{array}$ & 9/2004 \\
\hline $5 / 2004$ & $\begin{array}{l}\text { Kölling, A, } \\
\text { Rässler, S. }\end{array}$ & $\begin{array}{l}\text { Editing and multiply imputing German estab- } \\
\text { lishment panel data to estimate stochastic } \\
\text { production frontier models }\end{array}$ & $10 / 2004$ \\
\hline $6 / 2004$ & $\begin{array}{l}\text { Stephan, G, } \\
\text { Gerlach, K. }\end{array}$ & $\begin{array}{l}\text { Collective Contracts, Wages and Wage } \\
\text { Dispersion in a Multi-Level Model }\end{array}$ & $10 / 2004$ \\
\hline 7/2004 & $\begin{array}{l}\text { Gartner, H. } \\
\text { Stephan, G. }\end{array}$ & $\begin{array}{l}\text { How Collective Contracts and Works Councils } \\
\text { Reduce the Gender Wage Gap }\end{array}$ & $12 / 2004$ \\
\hline 1/2005 & $\begin{array}{l}\text { Blien, U., } \\
\text { Suedekum, J. }\end{array}$ & $\begin{array}{l}\text { Local Economic Structure and Industry } \\
\text { Development in Germany, 1993-2001 }\end{array}$ & $1 / 2005$ \\
\hline $2 / 2005$ & $\begin{array}{l}\text { Brixy, U., } \\
\text { Kohaut, S., } \\
\text { Schnabel, C. }\end{array}$ & $\begin{array}{l}\text { How fast do newly founded firms mature? } \\
\text { Empirical analyses on job quality in start-ups }\end{array}$ & $1 / 2005$ \\
\hline $3 / 2005$ & $\begin{array}{l}\text { Lechner, M., } \\
\text { Miquel, R., } \\
\text { Wunsch, C. }\end{array}$ & $\begin{array}{l}\text { Long-Run Effects of Public Sector Sponsored } \\
\text { Training in West Germany }\end{array}$ & $1 / 2005$ \\
\hline $4 / 2005$ & $\begin{array}{l}\text { Hinz, Th., } \\
\text { Gartner, H. }\end{array}$ & $\begin{array}{l}\text { Lohnunterschiede zwischen Frauen und } \\
\text { Männern in Branchen, Berufen und Betrieben }\end{array}$ & $2 / 2005$ \\
\hline $5 / 2005$ & $\begin{array}{l}\text { Gartner, H., } \\
\text { Rässler, S. }\end{array}$ & $\begin{array}{l}\text { Analyzing the Changing Gender Wage Gap } \\
\text { based on Multiply Imputed Right Censored } \\
\text { Wages }\end{array}$ & $3 / 2005$ \\
\hline
\end{tabular}


6/2005 Alda, H., Bender, S., Gartner, $\mathrm{H}$.

7/2005 Haas, A., Rothe, Th.
The linked employer-employee dataset of the IAB (LIAB)

Labour market dynamics from a regional perspective

The multi-account system

8/2005 Caliendo, M., Identifying Effect Heterogeneity to Improve Hujer, R., Thomsen, S.L. Germany

9/2005 Gerlach, K., Stephan, G.

10/2005 Gerlach, K., Individual Tenure and Collective Contracts Stephan, G.

11/2005 Blien, U., Hirschenauer, F.

Formula allocation: The regional allocation of budgetary funds for measures of active labour market policy in Germany

12/2005 Alda, H., Allaart, P., Bellmann, L.

Churning and institutions - Dutch and German establishments compared with micro-level data

$13 / 2005$ Caliendo, M., Hujer, R., Thomsen, St.

Individual Employment Effects of Job Creation Schemes in Germany with Respect to Sectoral Heterogeneity

14/2005 Lechner, M.; The Curse and Blessing of Training the Miquel, R., $\quad$ Unemployed in a Changing Economy Wunsch, C. - The Case of East Germany after Unification

15/2005 Jensen, U.; Where have all the data gone? Stochastic Rässler, S. $\quad$ production frontiers with multiply imputed German establishment data

16/2005 Schnabel, C.; Collective bargaining structure and ist deterZagelmeyer, minants: An empirical analysis with British and S.; Kohaut, S. German establishment data

17/2005 Koch, S.; Workfare: Möglichkeiten und Grenzen $8 / 2005$ Stephan, G.; Walwei, U.

18/2005 Alda, H., Bellmann, L., Gartner, $\mathrm{H}$.

$3 / 2005$

$4 / 2005$

$4 / 2005$

$4 / 2005$

$4 / 2005$

$4 / 2005$

$5 / 2005$

$5 / 2005$

$6 / 2005$

$7 / 2005$

$8 / 2005$

Wage Structure and Labour Mobility in the

$8 / 2005$ 


\section{Impressum}

IABDiscussionPaper

No. 19 / 2005

\section{Herausgeber}

Institut für Arbeitsmarkt- und Berufsforschung der Bundesagentur für Arbeit

Weddigenstr. 20-22

D-90478 Nürnberg

\section{Redaktion}

Regina Stoll, Jutta Palm-Nowak

Technische Herstellung Jutta Sebald

\section{Rechte}

Nachdruck - auch auszugsweise - nur mit Genehmigung des IAB gestattet

\section{Bezugsmöglichkeit}

Volltext-Download dieses DiscussionPaper

unter:

http://doku.iab.de/discussionpapers/2005/dp1905.pdf

\section{IAB im Internet}

http://www.iab.de

\section{Rückfragen zum Inhalt an}

Regina Konle-Seidl, Tel. 0911/179-3244, oder e-Mail: regina.konle-seidl@iab.de 